\title{
Studies on mycotoxin analysis using immunoaffinity column (2002 Japanese Association of Mycotoxicology Achievement Award)
}

\author{
Masahiro NAKAJIMA \\ Food Department, Nagoya City Public Health Research Institute \\ (1-11, Hagiyama-cho, M izuho-ku, Nagoya 467-8615, Japan)
}

\begin{abstract}
Summary
The traditional analysis of mycotoxins in food and feed required considerable time, large volume of solvents and often, special techniques. To overcome these problems, we developed the new analytical method for ochratoxin A (OTA) using the immunoaffinity column (IAC) specific for ochratoxin A (OTA) in 1990. The advantage of this method was one-step removal of interfering substances from samples. M oreover, the detection limit of $0.05 \mu \mathrm{g} / \mathrm{kg}$ for OTA in coffee beans was achieved. Using the IAC cleanup and HPLC with fluorometric or electrochemical detection, the surveys of aflatoxins (AFs) and OTA in green and roasted coffee beans, AFs in spices, and AFs, OTA, zearalenone (ZEN) and $\beta$-zearalenol ( $\beta$-ZEL) in beers were conducted. With the use of IACs in the cleanup steps, the parts-per-trillion ranges of mycotoxins were detectable. The detection limits were $0.004 \mathrm{~g} / \mathrm{kg}$ for $A F B_{1}$ in coffee beans and spices, and $0.05 \mu \mathrm{g} / \mathrm{kg}$ for OTA in coffee beans, $0.0005 \mu \mathrm{g} / \mathrm{L}$ for AFB ${ }_{1}, 0.001 \mathrm{q} \mathrm{g} / \mathrm{L}$ for OTA, $0.020 \mu \mathrm{g} / \mathrm{L}$ for ZEN and $\beta$-ZEL in beer samples. This paper also describes the effects of the elimination of fungi, $A F B_{1}$ and OTA in green coffee beans by handpicking.
\end{abstract}

Key words: immunoaffinity column, aflatoxins, ochratoxin $A, \beta$-zearalenol, coffee beans, spice, beer

(Received: August 14, 2002)

\section{Introduction}

To minimize the interferences of co-extracted compounds from food and feed samples in which mycotoxins occur, the conventional chemical analyses for mycotoxins are highly time-consuming, need large amount of solvents, and mostly require practical experiences. From the environmental point of view, toxic solvents such as chlorinated solvents should be saved from now on. Under these circumstances, the immunoaffinity column (IAC) methods using specific antibodies against mycotoxins have been developed. The major advantages of the IAC are highly specific, simple, rapid, and saving toxic solvents. The first IAC for aflatoxins (AFs) was developed by Groopman et al ${ }^{1)}$ in 1984, and we first reported the IAC method for ochratoxin A (OTA) ${ }^{2)}$ in 1990. Recently, with the availability of commercial IACs for AFs, OTA, zearalenone (ZEN), fumonisins and deoxynivalenol $(D O N)$, these IACs have become the powerful tools in the cleanup stage of mycotoxin analysis. M oreover, because of the robustness, accuracy, and precision of IAC method, the AOAC International Official M ethods of Analysis (OMA) has adapted 8 IAC methods for mycotoxin analysis.

Since the end of 1980s, we have surveyed mycotoxins in coffee beans, spices and beer samples 
using the IAC cleanup. This paper summarizes those results, including the development of IAC specific for OTA and the effects of the elimination of fungi, AFB ${ }_{1}$ and OTA in green coffee beans by handpicking.

\section{Development of the IAC specific for OTA}

For analyzing OTA in foods, most of the ordinary methods were time-consuming in the cleanup steps, and used a large volume of organic solvents such as chloroform. M oreover, it was difficult to detect low $\mu \mathrm{g} / \mathrm{kg}$ range of OTA in coffee samples by the conventional chemical methods, because coffee samples contain lots of fluorescent substances, which interfere TLC or HPLC-fluorometric $(F L)$ detection. Under these circumstances, we developed the new analytical method for OTA using a monoclonal antibody (MAb)-IAC in the cleanup step ${ }^{2,3)}$. M ain procedures of the IAC method were as follows. The anti-OTA M Ab was coupled to Formyl-cellufine (Seikagaku Co., Tokyo, Japan), and then this immunosorbent was placed in a minicolumn. The capacity of IAC to bind OTA was 0.8-1.0 $\mathrm{g}$ per $0.3 \mathrm{ml}$ of the column. The coffee sample was extracted with $1 \%$ sodium hydrogen carbonate solution, and filtered through a glass microfiber filter. The filtrate was applied onto the IAC. After washing the column with water, OTA was eluted with $30 \%$ ethanol solution ( $\mathrm{pH} \mathrm{4.4).} \mathrm{The} \mathrm{eluate} \mathrm{was} \mathrm{subject} \mathrm{to}$ HPLC using an alkaline mobile phase. The advantage of this method was one-step removal of interfering substances from samples. M oreover, with the alkali-conditioned HPLC, the sensitivity was increased more than 100-fold compared to the conventional method. The detection limit of this method was $0.05 \mu \mathrm{g}$ OTA/ $\mathrm{kg}$ for coffee samples.

\section{Survey of AFs and OTA in coffee beans}

As for the contamination of AFs or OTA in green coffee beans, Levi et al. ${ }^{4}$ first reported that 3 out of 68 samples were contaminated with $20-80 \mu \mathrm{g} / \mathrm{kg}$ of OTA, and Levi ${ }^{5}$ reported the contamination of $A F B_{1}$ in 2 out of 201 samples at 3 and $12 \mu \mathrm{g} / \mathrm{kg}$. Tsubouchi et al. ${ }^{6}$ also reported that 4 out of 22 samples were contaminated with $9.9-46 \mu \mathrm{g} / \mathrm{kg}$ of OTA. A few papers described that caffeine in green

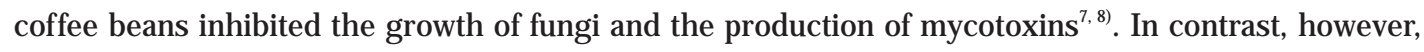
Tsubouchi et al. ${ }^{6,9)}$ reported that some strains of Aspergillus ochraceus and A. flavus isolated from green coffee beans grew well and produced high levels of OTA and AFB $B_{1}$ in the presence of $0.1 \%-1.0 \%$ caffeine. Furthermore, it was demonstrated that OTA in green coffee beans was not degraded by roasting procedures, and the most OTA in beans transmitted into the beverage ${ }^{10)}$. In addition, Tsubouchi et al. ${ }^{11}$ first reported the presence of OTA in commercial roasted coffee beans in 5 out of 68 samples at a level of $3.2-17.0 \mu \mathrm{g} / \mathrm{kg}$, at similar levels to green coffee beans reported previously. These results show that the contamination of mycotoxins in green coffee beans has the potential for affecting the human health.

The ordinary HPLC-FL detection of mycotoxins in coffee beans gives many interfering fluorescent peaks, which prevents detection of minor amounts of mycotoxins. However, with the introducing of the IAC in the cleanup steps, the HPLC profiles showed no significant interfering peaks (Fig.1), and allowed detection of the parts-per-trillion levels of $A F B_{1}$ and OTA in green coffee beans. 


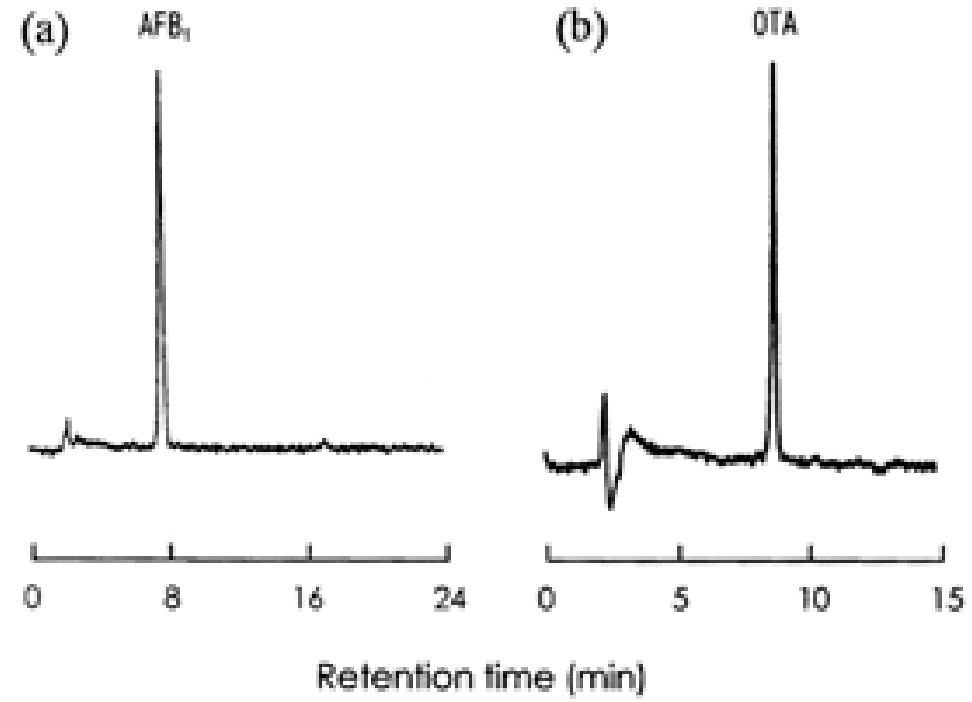

Fig. 1. Chromatograms of (a) AFB 1 in green coffee beans, $0.033 \mathrm{ppb}$ and (b) OTA in green coffee beans, $2.1 \mathrm{ppb}$.

Using the IAC cleanup followed by HPLC-FL detection, commercial green and roasted coffee beans were surveyed for AFs and OTA. As shown in Table $1, A F B_{1}$ was detected in 27 out of 96 green coffee samples at a level of $0.002-0.033 \mu \mathrm{g} / \mathrm{kg}$, and not detected from roasted coffee samples. OTA was detected in 50 out of 121 green coffee samples at a level of $0.07-72.68 \mu \mathrm{g} / \mathrm{kg}$, and also detected in 4 out of 26 roasted coffee samples at a level of $0.10-8.91 \mu \mathrm{g} / \mathrm{kg}$ (Table 2). The samples contaminated with OTA and/or $\mathrm{AFB}_{1}$ were mainly products imported from African and Asian countries. The mycological survey revealed that members of the A. niger group were prominent in the mycoflora of the green coffee beans examined (data not shown). So, OTA production by the A. niger group isolated from green coffee beans was examined. The data revealed that 2 out of 30 isolates from samples produced 0.56 and $0.08 \mu \mathrm{g} / \mathrm{kg}$ of OTA in rice culture, so it is possible to assume that the A. niger group is partly responsible for the OTA contamination in coffee beans.

Table 1. Aflatoxins (AFs) in commercial green and roasted coffee beans

\begin{tabular}{lccccc}
\hline \multirow{2}{*}{ Sample } & No. of samples & No. of positives & \multicolumn{3}{c}{ Range $(\mu \mathrm{g} / \mathrm{kg})$} \\
\cline { 4 - 6 } & & & $\mathrm{AFB}_{1}$ & $\mathrm{AFB}_{2}$ & $\mathrm{AFG}_{1}$ \\
\hline Green coffee beans & 96 & 27 & $0.002-0.033$ & $0.004-0.006$ & 0.012 \\
Roasted coffee beans & 18 & 0 & ND ${ }^{a}$ & ND & ND \\
\hline
\end{tabular}

${ }^{a} \mathrm{ND}=$ not detected (less than detection limit of $0.002 \mu \mathrm{g} \mathrm{AFs} / \mathrm{kg}$ ).

Table 2. Ochratoxin A (OTA) in commercial green and roasted coffee beans

\begin{tabular}{lccc}
\hline \multicolumn{1}{c}{ Sample } & No. of samples & No. of positives & $\begin{array}{c}\text { Range of OTA }{ }^{a} \\
(\mu \mathrm{g} / \mathrm{kg})\end{array}$ \\
\hline Green coffee beans & 121 & 50 & $0.07-72.68$ \\
Roasted coffee beans & 26 & 4 & $0.10-8.91$ \\
\hline
\end{tabular}

a Detection limit is $0.05 \mu \mathrm{g} / \mathrm{kg}$ 


\section{Elimination of mycotoxins in green coffee beans by handpicking}

Because of the heat stability of AFs and OTA ${ }^{10,12)}$, it is very important how to eliminate the mycotoxins in green coffee beans. We examined the effect of the elimination of fungi, and $A F B_{1}$ and OTA in green coffee beans by the handpicking method to remove the defective beans that make bad taste of coffee beverage ${ }^{13)}$. Each green coffee beans sample imported from Indonesia, Yemen, Tanzania, and Brazil was divided into 2 groups; 1) the good beans after handpicking, 2) the bad beans, which were the defective beans such as worm-eaten spot beans, mold beans, shell beans, dead beans, discoloration beans, fermentation beans, parchment beans after handpicking. AFB ${ }_{1}$ and OTA were analyzed by the IAC cleanup and HPLC-FL detection. As showed in Table 3, the mean numbers of fungi in the good beans were about two-third to one-tenth of that of the bad beans. This handpicking method also reduced the mean levels of both $A F B_{1}$ and OTA in the good beans compared to bad beans (Table 4, 5). In this way, the handpicking method removing the defective beans was very effective to eliminate the mycotoxins and fungi in green coffee beans.

Table 3. Numbers of fungi in green coffee beans after handpicking

\begin{tabular}{|c|c|c|c|}
\hline \multirow[t]{2}{*}{ Country } & \multirow[t]{2}{*}{ No. of samples } & \multicolumn{2}{|c|}{$\begin{array}{c}\text { M ean No. of fungi } \\
\left(\text { range } \times 10^{2} \mathrm{CFU} \text { a/g) }\right.\end{array}$} \\
\hline & & Good beans & Bad beans \\
\hline Indonesia & 6 & $\begin{array}{c}400 \\
(0.3-840)\end{array}$ & $\begin{array}{c}600 \\
(0.8-1250)\end{array}$ \\
\hline Yemen & 6 & $\begin{array}{c}100 \\
(0.8-530)\end{array}$ & $\begin{array}{c}940 \\
(1.3-5500)\end{array}$ \\
\hline Tanzania & 5 & $\begin{array}{c}20 \\
(1-56)\end{array}$ & $\begin{array}{c}66 \\
(18-220)\end{array}$ \\
\hline Brazil & 5 & $\begin{array}{c}1.4 \\
(0-2.5)\end{array}$ & $\begin{array}{c}13 \\
(3.2-30)\end{array}$ \\
\hline
\end{tabular}

${ }^{\text {a }} \mathrm{CFU}=$ colony forming units

Table 4. Contamination levels of aflatoxin $B_{1}\left(A F B_{1}\right)$ in green coffee beans after handpicking

\begin{tabular}{|c|c|c|c|c|}
\hline \multirow[b]{2}{*}{ Country } & \multicolumn{2}{|c|}{ Good beans } & \multicolumn{2}{|c|}{ Bad beans } \\
\hline & Incidence & $\begin{array}{c}\text { M ean levels of } A F B_{1}{ }^{a} \\
(\text { range }, \mu \mathrm{g} / \mathrm{kg})\end{array}$ & Incidence & $\begin{array}{l}\text { M ean levels of } A F B_{1} \\
(\text { range, } \mu \mathrm{g} / \mathrm{kg})\end{array}$ \\
\hline Indonesia & $3 / 6$ & $\begin{array}{c}0.002 \\
(0.004-0.006)\end{array}$ & $4 / 6$ & $\begin{array}{c}0.022 \\
(0.003-0.101)\end{array}$ \\
\hline Yemen & $2 / 6$ & $\begin{array}{c}0.001 \\
(0.002,0.004)\end{array}$ & $3 / 6$ & $\begin{array}{c}0.004 \\
(0.002-0.018)\end{array}$ \\
\hline Tanzania & $0 / 5$ & $\begin{array}{l}-b \\
-\end{array}$ & $1 / 5$ & $\begin{array}{l}0.0004 \\
(0.002)\end{array}$ \\
\hline Brazil & $0 / 5$ & - & $0 / 5$ & $\begin{array}{l}- \\
-\end{array}$ \\
\hline
\end{tabular}

a $M$ ean values were calculated by assuming that samples containing levels less than detection limit $(0.002 \mathrm{~g} / \mathrm{kg})$ contained $A F B_{1}$ at $0 \mu \mathrm{g} / \mathrm{kg}$.

b - = not applicable. 
Table 5. Contamination levels of ochratoxin A (OTA) in green coffee beans after handpicking

\begin{tabular}{|c|c|c|c|c|}
\hline \multirow[b]{2}{*}{ Country } & \multicolumn{2}{|c|}{ Good beans } & \multicolumn{2}{|c|}{ Bad beans } \\
\hline & Incidence & $\begin{array}{l}\text { M ean levels of OTA } \\
\quad(\text { range }, \mu \mathrm{g} / \mathrm{kg})\end{array}$ & Incidence & $\begin{array}{l}\text { M ean levels of OTA } \\
\text { (range, } \mu \mathrm{g} / \mathrm{kg})\end{array}$ \\
\hline Indonesia & $2 / 6$ & $\begin{array}{c}0.04 \\
(0.08,0.13)\end{array}$ & $4 / 6$ & $\begin{array}{c}0.86 \\
(0.38-4.78)\end{array}$ \\
\hline Yemen & $4 / 6$ & $\begin{array}{c}1.75 \\
(0.22-7.67)\end{array}$ & $6 / 6$ & $\begin{array}{c}21.04 \\
(2.73-72.70)\end{array}$ \\
\hline Tanzania & $1 / 5$ & $\begin{array}{c}0.03 \\
(0.13)\end{array}$ & $2 / 5$ & $\begin{array}{c}0.74 \\
(0.69,3.00)\end{array}$ \\
\hline Brazil & $0 / 5$ & $\begin{array}{l}-b \\
-\end{array}$ & $1 / 5$ & $\begin{array}{c}0.02 \\
(0.08)\end{array}$ \\
\hline
\end{tabular}

a $M$ ean values were calculated by assuming that samples containing levels less than detection limit $(0.05 \mu \mathrm{g} / \mathrm{kg})$ contained OTA at $0 \mu \mathrm{g} / \mathrm{kg}$.

b - = not applicable.

\section{Survey of fungi and AFs in spices}

Recently, with a change of the Japanese favorite foods, their consumption of spices has increased. In Japan, more than $98 \%$ of spices are imported, and their origins are tropical, sub-tropical countries where AFs contamination may be expected to occur. In Japan, only a few papers have described the contamination of AFs with a limited survey of each spice. In general, the contamination levels of AFs in spices are low except for chilli, pepper and nutmeg. However, many aflatoxigenic A. flavus are isolated from the spices, the production of AFs may occur when the fungi survive and multiply under favorable conditions. Under these circumstances, we surveyed the fungi and AFs in imported spices. Two hundred and fifty-seven samples were collected in Nagoya City from 1990 to 2001, and these samples were divided into seven types such as fruits, seeds, leaves, roots, barks, flowers, and mixed spices (Table 6). The most spices contain lots of fluorescent substances that interfere AFs analysis by HPLC-FL detection. By introducing the IAC method into the cleanup stage, no interfering peaks appeared on the chromatogram of HPLC, and the detection limit of $A F B_{1}$ was achieved at $0.002 \mu \mathrm{g} / \mathrm{kg}$.

Though about $50 \%$ of spices had total fungal counts of less than $10^{2} \mathrm{CFU} / \mathrm{g}$, about $17 \%$ of spices, which were mainly fruits, leaves and flowers, had total fungal counts of more than $10^{4} / \mathrm{g}$. Six AFproducing strains of $A$. flavus were isolated from the spices, such as cayenne pepper, paprika, black pepper, and gharum masala. These strains produced $A F B_{1}$ and $B_{2}$, moreover, one strain from paprika produced $A F B_{1}, B_{2}, G_{1}$, and $G_{2}$ (data not shown). As shown in Table $6, A F B_{1}$ was detected in 47 out of 257 samples ( $18.3 \%$ with the range of $0.002-8.7 \mu \mathrm{g} / \mathrm{kg} . A F B_{1}, B_{2}$ and $G_{1}$ was detected from fruits spices such as white pepper, paprika, and nutmeg, and $A F B_{1}, B_{2}, G_{1}$, and $G_{2}$ were detected from one sample of paprika. A high incidence of $A F B_{1}$ was occurred in fruits spices (25.7\%) such as red pepper, black pepper, paprika and nutmeg, and in mixed spices ( $88.8 \%$. A low incidence of $A F B_{1}$ was occurred in seeds, leaves and barks spices, and these contamination levels were equal or less than $0.09 \mu \mathrm{g} / \mathrm{kg}$. 
Table 6. Incidence and levels of aflatoxins (AFs) in Spices

\begin{tabular}{|c|c|c|c|c|c|c|c|}
\hline & \multirow{2}{*}{ Spice } & \multirow{2}{*}{$\begin{array}{c}\text { No. of } \\
\text { samples }\end{array}$} & \multirow{2}{*}{$\begin{array}{c}\text { No. of } \\
\text { positives }\end{array}$} & \multicolumn{4}{|c|}{ Range $(\mu \mathrm{g} / \mathrm{kg})$} \\
\hline & & & & $A F B_{1}$ & $\mathrm{AFB}_{2}$ & $A F G_{1}$ & $\mathrm{AFG}_{2}$ \\
\hline \multirow{11}{*}{ Fruits } & Red pepper & 16 & 5 & $0.007-0.595$ & $0.007-0.031$ & $N D^{a}$ & ND \\
\hline & Pink pepper & 1 & 1 & 0.007 & ND & ND & ND \\
\hline & Black pepper & 34 & 6 & $0.003-0.726$ & $0.052-0.350$ & ND & ND \\
\hline & White pepper & 14 & 5 & $0.002-0.265$ & $0.003-0.012$ & 0.007 & ND \\
\hline & Paprika & 5 & 3 & $0.043-3.230$ & $0.137-0.005$ & 0.996 & 0.040 \\
\hline & Nutmeg & 17 & 5 & $0.055-7.770$ & $0.013-0.780$ & 0.038 & ND \\
\hline & M ace & 10 & 1 & 0.010 & ND & ND & ND \\
\hline & Cayenne pepper & 1 & 1 & 0.007 & ND & ND & ND \\
\hline & Chinese pepper & 6 & 0 & ND & ND & ND & ND \\
\hline & Juniper berry & 1 & 0 & ND & ND & ND & ND \\
\hline & Total & 105 & 27 & & & & \\
\hline \multirow{7}{*}{ Seeds } & Coriander & 12 & 3 & $0.012-0.090$ & $0.007-0.008$ & ND & ND \\
\hline & Cardamon & 11 & 1 & 0.002 & ND & ND & ND \\
\hline & Cumin & 11 & 1 & 0.017 & ND & ND & ND \\
\hline & Fennel & 11 & 0 & ND & ND & ND & ND \\
\hline & Poppy seed & 3 & 1 & 0.084 & 0.008 & ND & ND \\
\hline & Others & 4 & 0 & ND & ND & ND & ND \\
\hline & Total & 52 & 6 & & & & \\
\hline \multirow{7}{*}{ Leaves } & Thyme & 11 & 1 & 0.007 & ND & ND & ND \\
\hline & Sage & 10 & 0 & ND & ND & ND & ND \\
\hline & Oregano & 11 & 0 & ND & ND & ND & ND \\
\hline & M arjoram & 11 & 0 & ND & ND & ND & ND \\
\hline & Rosemary & 11 & 0 & ND & ND & ND & ND \\
\hline & Others & 5 & 0 & ND & ND & ND & ND \\
\hline & Total & 59 & 1 & & & & \\
\hline \multirow{4}{*}{ Roots } & Turmeric & 2 & 2 & $0.027-0.100$ & ND & ND & ND \\
\hline & Ginger & 15 & 2 & 0.003 & ND & ND & ND \\
\hline & Others & 4 & 0 & ND & ND & ND & ND \\
\hline & Total & 21 & 5 & & & & \\
\hline Barks & Cinnamon & 10 & 0 & ND & ND & ND & ND \\
\hline \multirow{4}{*}{$\begin{array}{l}\text { M ixed } \\
\text { spices }\end{array}$} & Chilli powder & 3 & 3 & $1.470-8.700$ & $0.134-0.170$ & ND & ND \\
\hline & Curry powder & 5 & 4 & $0.050-0.302$ & $0.010-0.045$ & ND & ND \\
\hline & Gharum masala & 1 & 1 & 0.079 & 0.01 & ND & ND \\
\hline & Total & 9 & 8 & & & & \\
\hline \multirow[t]{2}{*}{ Flowers } & Cloves & 1 & 0 & ND & ND & ND & ND \\
\hline & Total & 257 & 47 & & & & \\
\hline
\end{tabular}

${ }^{\mathrm{a}} \mathrm{ND}=$ not detectable (less than detection limit of $0.002 \mathrm{AFs} \mu \mathrm{g} / \mathrm{kg}$ ).

\section{Survey of mycotoxins in imported and domestic beer}

The possibility of mycotoxins getting into beer from contaminated grains used in brewing was pointed out in the early 1970s, and mycotoxins such as AFs, OTA, ZEN and DON in beer recently reviewed ${ }^{144}$. Since 1994, with the use of IAC in the cleanup steps, detection limit has improved to the 
parts-per-trillion range, and many incidences of OTA contamination of beer have been reported, although levels were very low. Also the parts-per-trillion levels of AFs have been found in M exican and Brazilian beers ${ }^{15)}$. On the other hand, ZEN has no detected in beer samples in recent surveys. As that reason, some papers have reported that ZEN has been converted to its related compounds, such as $\beta$-zearalenol ( $\beta$-ZEL), $\alpha$-zearalenol ( $\alpha$-ZEL), and zearalanone (ZAN), by brewing strains Saccharomyces cerevisiae. So, it is necessary to analyze not only ZEN but also $\beta-Z E L$ in beer samples.

In 1998, we surveyed OTA and AFs in 94 imported beer samples from 31 producing countries and in 22 Japanese beer samples by using the IAC cleanup and HPLC-FL detection ${ }^{16}$. The detection limits were $0.0010 \mu \mathrm{g} / \mathrm{L}$ for OTA, $0.0005 \mu \mathrm{g} / \mathrm{L}$ for $A F s B_{1}$ and $B_{2}$, and $0.0010 \mu \mathrm{g} / \mathrm{L}$ for $A F s G_{1}$ and $G_{2}$. OTA was detected in 86 out of 94 imported beer samples at a mean level of $0.0101 \mu \mathrm{g} / \mathrm{L}$ and in 21 out of 22 Japanese beer samples at a mean level of $0.0125 \mu \mathrm{g} / \mathrm{L}$. AFB ${ }_{1}$ was detected in 11 out of 94 imported beer samples at a level of $0.0005-0.0831 \mu \mathrm{g} / \mathrm{L}$ and 2 out of $22 \mathrm{~J}$ apanese beer samples at 0.0005 and $0.0008 \mu \mathrm{g} / \mathrm{L}$ (data not shown). Although OTA was detected in most samples from various countries, AFs were detected in the beer samples from only a limited number of countries where AF contamination might be expected to occur because of their warm climate.

In 2000, we surveyed AFs, OTA, ZEN, and $\beta$-ZEL in beer samples. In the ordinal analysis of ZEN, HPLC-fluorescence detection has been widely used, however, the fluorescence intensity of $\beta$-ZEL is very low, and other related compounds such as $\mathbf{A}-\mathrm{ZEL}$ or ZAN cannot be detected. However, the introduction of the IAC cleanup and electrochemical detection to HPLC increased the sensitivity of ZEN and its related compounds. The detection limit of ZEN and its related compound was achieved at $0.020 \mu \mathrm{g} / \mathrm{L}$.

As shown in Table 7, ZEN was detected in 3 samples only from American beer at a level of 0.034 $0.069 \mu \mathrm{g} / \mathrm{ml}$. $\beta$-ZEL was detected in 29 out of 94 imported beer samples at a level of $0.020-0.838 \mu \mathrm{g} / \mathrm{ml}$ and 2 out of 14 Japanese beer samples at 0.099 and $0.174 \mu \mathrm{g} / \mathrm{ml}$. High incidence of $\beta$-ZEL contamination was observed in North, Central, and South American beer samples. The contamination levels and incidences of OTA and AF s were the same as the former study as follows. OTA was detected in 86 out of 94 imported beer samples at a mean level of $0.0178 \mu \mathrm{g} / \mathrm{L}$ and in 12 out of 14 Japanese beer samples at a mean level of $0.0161 \mu \mathrm{g} / \mathrm{L}$. AFB 1 was detected in 16 out of 94 imported beer samples at a level of $0.0009-0.0266 \mu \mathrm{g} / \mathrm{L}$ and 1 out of 22 J apanese beer samples at $0.0007 \mu \mathrm{g} / \mathrm{L}$ (data not shown).

\section{Concluding remarks}

The above analytical results demonstrate that the IAC method is well suited for the detection of mycotoxins at the parts-per-trillion level. With the availability of commercial IACs for mycotoxins, IAC method has emerged as an important cleanup technique in the mycotoxin analysis. M oreover, as the OMA of AOAC International has already adapted 8 IAC methods for mycotoxin analysis, the IAC method gives better precision and accuracy (e.g., RSD $R_{R}$ or HORRAT value) than that of conventional methods. The IAC method is expected to occupy an important position in mycotoxin analysis from now on increasingly.

The author express many thanks to Dr. Yoshio Ueno, Yashio Institute of Environmental Sciences, 
Table 7. Zearalenone (ZEN), $\beta$-zearalenol ( $\beta$-ZEL) in imported and J apanese beer samples

\begin{tabular}{|c|c|c|c|c|}
\hline \multirow[b]{2}{*}{ Region or country } & \multicolumn{2}{|c|}{ ZEN } & \multicolumn{2}{|c|}{$\beta-Z E L$} \\
\hline & Incidence & Range $(\mu \mathrm{g} / \mathrm{L})$ & Incidence & Range $(\mu \mathrm{g} / \mathrm{L})$ \\
\hline North America & $3 / 19$ & $0.034-0.069$ & $10 / 19$ & $0.029-0.838$ \\
\hline Canada & $0 / 3$ & $N D^{a}$ & $0 / 3$ & ND \\
\hline United States & $3 / 16$ & $0.034-0.069$ & $10 / 16$ & $0.029-0.838$ \\
\hline Central America & $0 / 8$ & ND & 4/ 8 & $0.182-0.357$ \\
\hline Jamaica & $0 / 1$ & ND & $0 / 1$ & ND \\
\hline M exico & $0 / 6$ & ND & $4 / 6$ & $0.182-0.357$ \\
\hline Trinidad & $0 / 1$ & ND & $0 / 1$ & ND \\
\hline South America & $0 / 3$ & ND & $2 / 3$ & $0.026,0.042$ \\
\hline Brazil & $0 / 2$ & ND & $1 / 2$ & 0.026 \\
\hline Peru & $0 / 1$ & ND & $1 / 1$ & 0.042 \\
\hline Oceania & $0 / 8$ & ND & $0 / 8$ & ND \\
\hline Australia & $0 / 3$ & ND & $0 / 3$ & ND \\
\hline New Zealand & $0 / 4$ & ND & $0 / 4$ & ND \\
\hline Tahiti & $0 / 1$ & ND & $0 / 1$ & ND \\
\hline Africa & $0 / 2$ & ND & $1 / 2$ & 0.022 \\
\hline Kenya & $0 / 1$ & ND & $1 / 1$ & 0.022 \\
\hline South Africa & $0 / 1$ & ND & $0 / 1$ & ND \\
\hline Europe & $0 / 40$ & ND & $10 / 40$ & $0.020-0.160$ \\
\hline Austria & $0 / 1$ & ND & $0 / 1$ & ND \\
\hline Belgium & $0 / 7$ & ND & $1 / 7$ & 0.160 \\
\hline Denmark & $0 / 3$ & ND & $1 / 3$ & 0.061 \\
\hline France & $0 / 3$ & ND & $0 / 3$ & ND \\
\hline Germany & $0 / 11$ & ND & 2/ 11 & $0.022,0.027$ \\
\hline Holland & $0 / 3$ & ND & $0 / 3$ & ND \\
\hline Italy & $0 / 3$ & ND & $3 / 3$ & $0.020-0.064$ \\
\hline Portugal & $0 / 2$ & ND & $2 / 2$ & $0.027,0.036$ \\
\hline United Kingdom & $0 / 7$ & ND & $1 / 7$ & 0.081 \\
\hline Asia & $0 / 14$ & ND & $3 / 14$ & $0.023-0.093$ \\
\hline China & $0 / 1$ & ND & $0 / 1$ & ND \\
\hline Indonesia & $0 / 2$ & ND & $0 / 2$ & ND \\
\hline Israel & $0 / 1$ & ND & $1 / 1$ & 0.093 \\
\hline Philippines & $0 / 2$ & ND & $1 / 2$ & 0.023 \\
\hline Singapore & $0 / 2$ & ND & $0 / 2$ & ND \\
\hline Taiwan & $0 / 1$ & ND & $1 / 1$ & 0.041 \\
\hline Thailand & $0 / 3$ & ND & $0 / 3$ & ND \\
\hline Vietnam & $0 / 2$ & ND & $0 / 2$ & ND \\
\hline Over all & $3 / 94$ & $0.034-0.069$ & $29 / 94$ & $0.020-0.838$ \\
\hline Japan & $0 / 14$ & ND & 2/ 14 & $0.099,0.174$ \\
\hline
\end{tabular}

${ }^{a} \mathrm{ND}=$ not detectable (less than detection limit of $0.020 \mathrm{ZEN}$ and $\beta-Z E L \mu \mathrm{g} / \mathrm{L}$ ).

ex-Professor of Science University of Tokyo for kindly donating anti-OTA monoclonal antibody used in this study, and for his kindly advices. The author also thank Dr. Haruo Tsubouchi, Dr. Hisaya Terada and Dr. Kazuo Hisada, the staff of Food Department of N agoya City Public Health Research Institute for the useful advices and for kindly providing the technical co-operations in this study. 


\section{References}

1 ) Groopman, J. D., Trude, L. J., D onahue, P. R., M arshak-Rothstein, A., Wogan, G. N.: Proc. Nat. Acad. Sci. USA, 81, 7728-7731 (1984)

2 ) Nakajima, M., Terada, H., Hisada, K., Tsubouchi, H., Yamamoto, K., Uda, T., Itoh, Y., Kawamura, O., Ueno, Y.: Food Agric. Immunol., 2, 189-195 (1990)

3 ) Nakajima, M ., Tsubouchi, H., M iyabe, M., U eno, Y.: Food Agric. Immunol., 9, 77-83 (1997)

4 ) Levi, C. P., Trenk, H. L., M ore, H. K.: J. Assoc. Off. Anal. Chem. 57, $866-870$ (1974)

5 ) Levi, C.: J. Assoc. Off. Anal. Chem., 63, 1282-1285 (1980)

6 ) Tsubouchi, H., Yamamoto, K., Hisada, K., Sakabe, Y.: Proc. J pn. Assoc. M ycotoxicol., 19, 16-21 (1984)

7 ) Buchanan, R. L., Fletcher, A. M .: J. Food Sci., 43, 654-655 (1978)

8 ) Buchanan, R. L., Tice, G., M arino, D.: J. Food Sci., 47, 319-321 (1981)

9 ) Tsubouchi, H., Yamamoto, K., Hisada, K., Sakabe, Y., U dagawa, S.: Proc. J pn. Assoc. M ycotoxicol., 20, 1016 (1984)

10) Tsubouchi, H., Yamamoto, K., Hisada, K., Sakabe, Y., Udagawa, S.: M ycopathologia, 97, 111-115 (1987)

11) Tsubouchi, H., Terada, H., Yamamoto, K., Sakabe, Y.: J. Agric. Food Chem., 36, 540-542 (1988)

12) Tabata, S., Kamimura, H., Tamura, Y., I be, A., Hashimoto, H., Nishima, T.: J. of Food Hyg. Soc. J apan, 33, 150-156 (1992)

13) Tsubouchi, H., Nakajima, M., Yamamoto, K., M iyabe, M .: Proc. J pn. Assoc. M ycotoxicol., 36, $45-48$ (1992)

14) Scott, P. M.: J. AOAC Int., 79, 875-882 (1996)

15) Scott, P. M., Lawrence, G. A.: J. AOAC Int., 80, 1229-1234 (1997)

16) Nakajima, M., Tsubouchi, H., M iyabe, M.: J. AOAC Int., 82, $897-902$ (1999) 
マイコトキシン分析へのイムノアフィニティーカラムの応用に関する研究 (学術賞奨励賞)

中島正博 : 名古屋市衛生研究所 食品部 (467-8615 名古屋市瑞穂区萩山町 1-11)

著者らは以前よりコーヒー豆及びコーヒー製品のオクラトキシンA (OTA) 污染調査を行っていたが， コーヒーに含まれている多量の夾雑物質のため, 微量なOTAを検出するのに煩雑な前処理操作が必要で あった，乥こで著者らはOTAに特異的なイムノアフィニティーカラム (IAC) を作製し,コーヒ一中のOTA 分析の前処理に応用したところ, 兴の微量定性分析における有用性が判明した .このIACにより試料中の OTA はワンステップで精製，濃縮することができ，HPLC-蛍光検出において $0.05 \mu \mathrm{g} / \mathrm{kg}$ の OTA が検出可 能となった . 著者らはこれまでに, 自作のOTAに特異的なIAC および市販のIAC を用いて,コーヒ一五の アフラトキシン (AFs) およびOTA 污染調査, 香辛料の AFs 污染調査, ビールの AF, OTA, ゼアラレノン (ZEN) およひß-ゼアラレノール (B-ZEL) 污染調査を行ってきた.これらの調査において, 試料からのマ イコトキシンの分離・精製にIAC を応用することにより，分析操作は簡便になり，しかも極微量 (pptレベ ル）のマイコトキシンを検出することが可能になった．弚こで今回は上記の研究結果に加え，選別による コーヒー豆のカビおよびマイコトキシン除去について述べる．

キーワード : イムノアフィニティーカラム, アフラトキシン , オクラトキシン A , $\beta$-ゼアラレノール コーヒ一豆, 香辛料, ビール 